\title{
Tugas Individu
}

\section{a. Judul :}

Solusi dari kendala perizinan budidaya udang di Indonesia

\section{b. Sitasi Jurnal :}

Pelaku usaha budidaya udang mengeluhkan peraturan perizinan usaha yang berbelitbelit. Saat ini terdapat 21 izin yang harus dipenuhi oleh petambak udang. Beberapa perizinan yang banyak dikeluhkan pembudidaya adalah Peraturan daerah yang menyebutkan bahwa kolam budidaya termasuk bangunan dan pungutannya dihitung per meter persegi. Pengoperasian genset yang digunakan sebagai cadangan listrik PLN juga tunduk pada 5 persyaratan perizinan, antara lain izin pengoperasian generator, sertifikat kelayakan pengoperasian genset, sertifikat kompetensi teknis operator genset, dan izin penyimpanan bahan bakar minyak. (Ahmad Zafrullah Tayibnapis, Lucia E. Wuryaningsih, \& Radita Gora, 2020)

\section{c. Artikel :}

Surat Izin Usaha Perikanan (SIUP) harus dimiliki perusahan perikanan atau perseorangan untuk melakukan usaha perikanan termasuk tambak udang. Perizinan adalah bentuk kepastian bahwa pelaku budidaya telah memenuhi standar budidaya yang baik, menjaga kelestarian alam, dan menjaga keselarasan dengan lingkungan sosial, serta menaati hukum yang berlaku. Perizinan yang dimiliki menjadi bukti legal tambak beroperasi.

Pengembangan budidaya udang di beberapa daerah masih banyak tantangan dan kendala terutama perizinan, tarif bea masuk, retribusi yang dikenakan pemerintah kabupaten/provinsi. Pelaku usaha dan pembudidaya berharap pemerintah untuk mulai menyederhanakan layanan perizinan maupun non-perizinan untuk komoditas perikanan khususnya udang. Penerapan sistem Pelayanan Terpadu Satu Pintu (PTSP) dianggap solusi terutama untuk pembudidaya dengan modal skala besar.

Fakta di lapangan, kualitas SDM (sumber daya manusia) pembudidaya juga masih menjadi kendala. Ketidak-tahuan berbagai hal termasuk upaya menjaga kualitas udang, wawasan, pembudidaya sering berurusan dengan aparat penegak hukum. Misalkan mengenai ketentuan penggunaan genset untuk menggerakkan kincir maupun 
pompa air. Bagi petambak udang, pasokan listrik yang bermasalah dari PLN membuat mereka harus mengeluarkan biaya lebih banyak bila harus menggunakan genset. Selama ini, para pengusaha tambak udang juga belum semuanya beralih pada penggunaan listrik PLN. Sementara genset berbahan bakar minyak tidak se-efisien penggunaan listrik. Permasalahan ini tentu saja berdampak buruk pada produksi udang. Bila pemerintah ingin meraih target pertumbuhan tinggi produksi udang, maka infrastruktur harus dibenahi dengan serius.

Menurut Ketua Umum SCI Iwan Sutanto, budidaya udang Indonesia harus didorong karena udang merupakan salah satu komoditas perikanan budidaya andalan utama Indonesia. "Bicara ekspor, ya pasti mengarah ke udang karena 60 persen dari ekspor udang Indonesia adalah udang hasil budidaya, Bahkan nilainya di atas tuna”. Senada dengan Iwan, Ketua AP5I Budhi Wibowo membenarkan bahwa udang merupakan komoditas dengan potensi perdagangan ekspor yang sangat besar. Menurutnya, ekspor udang Indonesia kurang lebih USD 1,8 miliar per tahun dengan jumlah lebih dari 200.000 ton. AP5I sendiri menurutnya mengolah udang dari pembudidaya udang sebesar kurang lebih 350.000 ton. Padahal menurutnya, AP5I memiliki kapasitas mesin pengolah sebesar 550.000 ton. "Jadi kami masih kekurangan bahan baku kurang lebih 200.000 ton. Nah, ini yang menyebabkan kami sulit bersaing di pasar internasional karena kapasitas dan utilitas kami hanya 60 persen," paparnya.

Menjawab harapan pelaku usaha budidaya tersebut, Menteri Edhy menegaskan bahwa sektor budidaya memang akan menjadi prioritas. Oleh karena itu, akan dilakukan optimalisasi salah satunya dengan melakukan pelimpahan wewenang perizinan budidaya udang kepada Badan Koordinasi Penanaman Modal (BKPM). Keputusan tersebut sekaligus upaya pemerintah dalam menarik investor dan pelaku usaha melalui mekanisme pelayanan satu pintu. Menteri KKP Edhy Prabowo mengatakan penyederhanaan izin diharapkan penyederhanaan perizinan ini bisa menjadi penyemangat bagi pelaku usaha budidaya, khususnya udang dan turut mendorong produktivitas udang nasional skala besar. Izin budidaya udang ini dipangkas menjadi satu pintu di BKPM dari sebelumnya diwajibkan mengurus 21 izin usaha.

Kebijakan ini sesuai dengan arahan Menteri Koordinator Kemaritiman dan Investasi Luhut Panjaitan, serta Kepala Staf Presiden Moeldoko. Lebih lanjut, meskipun dilakukan pemangkasan jalur perizinan, namun pemerintah tetap mengharuskan pelaku usaha untuk mengurus persetujuan aspek lingkungan. Selain 
kemudahan dalam legalitas pengurusan usaha, pemerintah juga menyiapkan akses permodalan kepada pengusaha. Salah satu yang kini gencar disebar adalah Kredit Usaha Rakyat (KUR).

\section{d. Detail Penulis :}

Nama : Dhanti Intansari Adji Wijaya

NRP : 130217327

$\mathrm{KP} \quad$ : A 